\title{
Восход и консолидация Исламского государства: внешняя интервенция и сектантский конфликт
}

\section{Абдул Басир Йосуфи}

Министерство внутренних дел, Исламская Республика Афганистан

Резюме: В этом исследовании рассматривается степень, в которой интервенция Соединенных Штатов (США) в 2003 году и сектантский конфликт в Ираке и регионе способствовали восходу и консолидации Исламского государства (ИГ). Автор считает, что интервенция США способствовала восходу ИГ, став стратегической причиной для мобилизации повстанческого движения при недостаточных контр-повстанческих ресурсах и отсутствии контр-повстанческой доктрины, а отсутствие послевоенного плана позволило консолидацию повстанческого движения. Хотя США адаптировали свою стратегию и развернули дополнительные ресурсы в качестве «волны», что привело к значительному ослаблению повстанцев, преждевременный вывод войск США способствовал оживлению повстанческого движения, которое в конечном итоге превратилось в ИГ. Затем восходу и консолидации ИГ помог сектантский конфликт в Ираке и в регионе, который способствовал распространению идеологий противоборствующих групп, расширил возможности для финансирования повстанцев и заставил суннитские общности поддержать Исламское Государство.

Ключевые слова: контр-повстанческие действия, повстанческое движение, Ирак, ИГИЛ, Исламское государство, сектантский конфликт, интервенция США.

\section{Введение}

В августе 2014 года, Исламское государство Ирака и Сирии (ИГИС) ошеломило мир, захватив второй по величине город Ирака, Мосул, информация о чем, как сейсмическая волна, обошла весь свет. Около 800 боевиков 
ИГИС разгромили иракские силы безопасности численностью предположительно в 30000 , которые побросали свое вооружение, сняли формы и бежали, спасая жизнь. Буквально за несколько недель боевики ИГИС захватили несколько других суннитских провинций, в том числе Ниневию, Салахуддин и части Диялы, подойдя к окрестностям иракской столицы Багдад. Еще более шокирующими были резня, в которой были убиты 1700 иракских солдат, и перемещение приблизительно полумиллиона людей, которые бежали от жестокостей террористической группировки после ее стремительного наступления. Вскоре после взятия Мосула, группировка официально сменила свое имя на Исламское государство и пригласила всех мусульман иммигрировать в новосозданный Халифат. Зверства, совершаемые ИГ, породили один из самых серьезных беженских и гуманитарных кризисов после конца Второй мировой войны, и эта группировка рассматривается как одна из самых серьезных угроз национальной безопасности.

В этой работе рассматриваются два параллельных вопроса: Как - и в какой степени - интервенция США в 2003 году и сектантский конфликт способствовали восходу и консолидации Исламского государства? Используя методологию изучения конкретных примеров, в этом исследовании внимание сосредоточено на вышеупомянутых факторах по следующим трем причинам. Во-первых, существует академический и исследовательский пробел в отношение этих двух факторов в случае Ирака. Было написано много работ по ИГ, в которых обсуждаются разные аспекты группировки, и многие политики бросают вину за восход группировки на интервенцию США и сектантскую политику премьер-министра Ирака Нури альМалики. Однако, в академической литературе можно найти мало работ с систематическим анализом, касающимся этих двух факторов, и механизма их вклада в восход ИГ. Во-вторых, эти два фактора считаются наиболее важными для восхода и консолидации ИГ. И в-третьих, исследование и анализ этих факторов может иметь существенные последствия не только для политики в отношение ИГ, но и для будущих внешних интервенций в этот регион.

\section{Интервенция США и подъем повстанческого движения}

Интервенция США в Ирак и ее последствия способствовали восходу и укреплению повстанческого движения, которое в конечном итоге превратилось в ИГ. Можно разными способами доказывать, что свержение Саддама Хусейна и его баасистского режима было неизбежным и являлось только вопросом времени. Он был одним из диктаторов, управлявших самое продолжительное время, он вторгся в две соседние страны, разрушил и привел к нищенству свою страну из-за ненужных конфронтаций с соседями и с Западом, и не испытывал угрызений совести, применяя химическое оружие против своего собственного народа. Он вышел из суннитской общности в Ираке, которая составляет около $20 \%$ от иракского населения, 
и подвергал гонениям шиитов и курдов, составляющих соответственно приблизительно 60-65\% и 15-20\% от иракского населения. Он мог быть свергнут Арабской весной, как случилось с Мубараком, Каддафи и Бен Али, или мог столкнуться с повстанческим движением, как Башар аль-Асад в соседней Сирии. Мы никогда этого не узнаем, как всегда это бывает тогда, когда чего-то не случилось. Однако, с уверенностью можно сказать, что если бы он оставался у власти, мир не стал бы свидетелем широкомасштабного суннитского повстанческого движения, которое в конечном итоге превратилось в Исламское государство.

Тогда как Аль-Каида была побочным продуктом советского нашествия в Афганистан, восходу ИГ способствовала интервенция США в Ираке в 2003 году. Советская инвазия, которая продолжилась десять лет с 1979 по 1989 год, привела к исламистскому повстанческому движению, привлекшему тысячи афганских и иностранных боевиков. США и их западные союзники поддерживали афганских моджахедов против Советов, обеспечивая их деньгами, оружием и подготовкой через пакистанскую межведомственную разведку (МВР). В течение этого периода много арабских боевиков, среди них Усама бен Ладен, прибыли в Афганистан, чтобы принять участие в джихаде против Советского Союза. Когда Советы ушли из Афганистана, многие из этих боевиков вернулись в свои страны и создали или включились в радикальные группы, борющиеся против их правительств. Используя контакты и репутацию, созданные в Афганистане, Усама бен Ладен в 1991 году основал Аль-Каиду, чтобы вести глобальную войну против Запада.

Абу Мусааб аль-Заркави был одним из радикалов, который встретился с бен Ладеном и его лейтенантами в Афганистане и стал руководить тренировочным лагерем в западной афганской провинции Герат. Он вернулся в Ирак, чтобы основать радикальное движение, Джамаат ат-Таухид вальДжихад (Группа единства и джихада) в 1999 году. Это движение развилось в Аль-Каиду в Ираке (АКИ), Исламское государство в Ираке, Исламское государство Ирака и Сирии (ИСИС) и наконец, в Исламское государство (ИГ). ${ }^{1}$

\section{Интервенция США как стратегическая причина для повстанче- ского движения}

По мнению французского теоретика контр-повстанческих действий, Давида Галула, первым предварительным условием для успешного повстанческого движения является существование стратегической идеи, которая

1 Mohammad-Mahmoud Ould Mohamedou, "ISIS and the Deceptive Rebooting of al Qaeda," GCSP Policy Paper 2014/5 (Geneva: GCSP, August 2014), по состоянию на 3 августа 2016 http://reliefweb.int/sites/reliefweb.int/files/resources/ISIS\%20and\% 20the\%20 Deceptive\%20Rebooting\%20of\%20Al\%20Qaeda.pdf, 2. 
могла бы привлечь значительное число людей. ${ }^{2}$ Это так потому, что лидеры повстанческого движения должны найти потенциальных приверженцев среди населения и убедить их активно или пассивно поддерживать повстанческое движение. K примеру, советская инвазия в Афганистан была атрактивной стратегической причиной не только для повстанцев внутри страны, но и со всего мусульманского мира, откуда к движению присоединились множество боевиков. Подобным образом, интервенция США в Ираке дала повстанцам стратегическую идею для привлечения боевиков и финансирования. Ресурсы, могущество и способности повстанцев никоим образом не сравнимы с ресурсами, могуществом и способностями США, но у них есть очень ценный нематериальный актив - идея борьбы с иностранным нашествием, - который помогает им привлекать значительное число приверженцев, помогает им воевать и продолжать развиваться.

\section{Интервенция США и популярность; Заркави и его группировка}

Хотя группировка Джамаат ат-Таухид валь-Джихад (Группа единства и джихада) была основана в 1999 году, только интервенция США в Ирак в 2003 году дала группировке и ее лидеру Заркави возможность возглавить широкомасштабное повстанческое движение со стратегической идеей бороться с внешним нашествием. Впервые Заркави попал в заголовки после нападений на Иорданское посольство и на комплекс Организации Объединенных Наций в Багдаде в августе 2003 года. ${ }^{3}$ Первоначально группа была создана для борьбы против существующих секуляристских правительств, но эта идея не была достаточно привлекательной, чтобы мобилизовать значительное число людей.

По мере того, как повстанческое движение набирало скорость после интервенции США в 2003 году, расширялась и деятельность группировки Заркави. За период с 2003 по 2005 год, группировка несет ответственность за $42 \%$ из всех самоубийственных терактов, которые привели к преобладающему числу человеческих потерь. ${ }^{4}$ Первая битва за Фалуджу, в которой повстанцы показали несгибаемую стойкость и обескровили самую сильную в мире армию, привела к увеличению публичной привлекательности и силы группировки Таухид валь-Джихад в Ираке. В октябре 2004 года, альЗаркави присягнул на верность Усаме бен Ладену, лидеру Аль-Каиды, и сменил имя группировки на Танзим Каидат аль-Джихад фи Билад аль-Рафидайн, или Аль-Каида земли Двуречья, которую часто называют Аль-Каидой в Ираке (АКИ). Вторая битва за Фалуджу, которая началась в начале ноября 2004 года и длилась шесть недель, прибавила еще известности аль-

2 David Galula, Counterinsurgency Warfare: Theory and Practice (Westport, Conn.: Greenwood Publishing Group, 2006), 17.

3 Ould Mohamedou, "ISIS and the Deceptive Rebooting of al Qaeda."

4 Patrick Cockburn, The Rise of Islamic State: ISIS and the New Sunni Revolution (New York: Verso Books, 2015), 28. 
Заркави и АКИ. В тактическом плане битва была выиграна вооруженными силами США, которые захватили город, причем потери повстанцев составили 2000 убитых по сравнению со всего 70 погибшими морскими пехотинцами США. Однако, разрушение города и перемещение гражданского населения стали бесценным пропагандистским инструментом для повстанцев. ${ }^{5}$

Аль-Заркави был убит при американском воздушном ударе 7 июня 2016 года, но АКИ продолжила воевать и развиваться. В октябре 2006 года, к АКИ присоединились некоторые другие повстанческие группы, чтобы создать Исламское государство в Ираке (ИГИ). Поскольку внешняя интервенция и сектантский конфликт продолжали подпитывать повстанческое движение, погибшие руководители заменялись другими, и группа продолжала развиваться. Приведенная ниже таблица показывает развитие Исламского государства с течением времени.

Таблица 1. Эволюция ИГИС.

\begin{tabular}{|l|l|l|}
\hline Конфигурация & Период & Лидер(ы) \\
\hline $\begin{array}{l}\text { Джамаат ат-Таухид валь- } \\
\text { Джихад }\end{array}$ & конец 1999-17 октября 2004 & Абу Мусаб аль-Заркави \\
\hline $\begin{array}{l}\text { Аль-Каида фи Билад аль- } \\
\text { Рафидайн }\end{array}$ & $\begin{array}{l}17 \text { октября 2004 - 15 января } \\
2006\end{array}$ & $\begin{array}{l}\text { Абу Мусаб аль-Заркави } \\
\text { Абу Омар аль-Багдади }\end{array}$ \\
\hline $\begin{array}{l}\text { Меджлис аль Шура аль- } \\
\text { Муджахидин }\end{array}$ & $\begin{array}{l}15 \text { января 2006-15 октября } \\
2006\end{array}$ & $\begin{array}{l}\text { Абу Хамза аль- } \\
\text { Мухаджир }\end{array}$ \\
\hline $\begin{array}{l}\text { Исламское государство } \\
\text { Ирака }\end{array}$ & $\begin{array}{l}15 \text { октября 2006 - } 9 \text { апреля } \\
2013\end{array}$ & $\begin{array}{l}\text { Абу Хамза аль- } \\
\text { Мухаджир } \\
\text { Абу Аюб аль-Масри } \\
\text { Абу Бакр аль-Багдади }\end{array}$ \\
\hline $\begin{array}{l}\text { Исламское государство } \\
\text { Ирака и аль-Шам }\end{array}$ & $\begin{array}{l}15 \text { октября 2006 - 29 июня } \\
2014\end{array}$ & Абу Бакр аль-Багдади \\
\hline Исламское государство & $\begin{array}{l}29 \text { июня 2014- настоящее } \\
\text { время }\end{array}$ & Абу Бакр аль-Багдади \\
\hline
\end{tabular}

Источник: GCSP Policy Paper 2014/5 - August 2014.

\section{Слабость контрповстанческой деятельности, возможность для расширения повстанческого движения}

Другим необходимым условием для успешного повстанческого движения, по мнению Галула, является слабость контрповстанческих, или правительственных сил. ${ }^{6}$ Слабость может быть политической, например, слабая легитимность; административной, например, неспособность обеспечить хорошее управление и работу; или военной, например, недостаточное количество ресурсов или войск. Независимо от того, что интервенция США дала

5 Там же, 34-35.

6 Galula, Counterinsurgency Warfare: Theory and Practice, 17. 
стратегический мотив для повстанческого движения, восход ИГ не был неизбежен, и хорошо спланированная и обеспеченная ресурсами контрповстанческая кампания могла бы привести к поражению восставших. Однако, имели место политическая, военная и административная слабость контрповстанческой кампании США, что позволило повстанческому движению подняться и консолидироваться.

\section{Политическая слабость и проблема легитимности}

Интервенция США в Ираке была спорной в юридической сфере с самого начала. Она не была одобрена резолюцией Совета безопасности ООН, чьи постоянные члены - Франция, Россия и Китай - были против интервенции. Более того, многие из союзников США в регионе и по всему свету, в том числе Германия, Турция, Канада, Саудовская Аравия и Иордания, возражали против интервенции. В интервью для ВBC News 16 сентября 2004 года, Генеральный секретарь ООН, Кофи Аннан, сказал, что «[война] не находится в соответствии с Уставом ООН с нашей точки зрения, и с точки зрения Устава она незаконна». 7

Президент США, Дж. У. Буш, заявил, что «наша миссия ясна, разоружить Ирак от оружия массового уничтожения, прекратить поддержку, оказываемую Саддамом Хуссейном террористам, и освободить иракский народ». Однако, вооруженные силы США не нашли никакого оружия для программы массового уничтожения, а правительство США даже обвинили в манипулировании разведывательной информацией для обоснования инвазии, хотя оно знало, что такой программы не существует. С другой стороны, интервенция не только не уменьшила терроризм, но и превратила террористов в глазах людей из головорезов и экстремистов в борцов за свободу.

Контрповстанческая деятельность является на первом месте политической кампанией для приобретения легитимности и завоевания умов и сердец населения. Тогда как у повстанцев имеется превосходящий мотив, субъекты, осуществляющие контрповстанческую деятельность, располагают ресурсами, необходимыми для обеспечения безопасности, управления и услуг для населения и для получения их поддержки. Политическим измерением войны в Ираке в большой степени пренебрегали, и не было никакого плана операций по обеспечению стабильности после поражения иракских вооруженных сил и свержения режима Саддама Хуссейна. До интервенции так же не было политической дорожной карты для политического будущего страны. Как было отмечено

7 Kofi Annan, “Excerpts: Annan Interview," ВВC News, September 16, 2004, по состоянию на 20 марта 2016, http://news.bbc.co.uk/2/hi/middle_east/3661640.stm.

8 George W. Bush, Radio Address, March 22, 2003, White House Archives, nо состоянию на 20 марта 2016, http://georgewbush-whitehouse.archives.gov/news/ releases/2003/03/20030322.html. 
Антони Кордесманом, «Правительство США не смогло разработать серьезный или эффективный план для 4 фазы войны, - периода окончания конфликта и создания эффективного управления государством». ${ }^{9}$

Таким образом, законность присутствия США среди иракского населения была еще больше подорвана, когда после падения Багдада последовали массовые беспорядки, грабежи и беззакония. Министр обороны США, Дональд Рамсфельд, подвергся критике за хаос, последовавший за интервенцией, и его ответ показателен для серьезности проблемы: «Свобода неопрятна, и свободные люди свободны делать ошибки, совершать преступления и делать плохие вещи. Они так же свободны жить своей жизнью и делать прекрасные вещи. И это должно случиться здесь». ${ }^{10}$

Отсутствие координации между Министерством обороны (МO) и Государственным департаментом (ГД) в период после интервенции усугубило эту проблему, что привело к тому, что окно возможностей для получения доверия и поддержки населения было упущено. ${ }^{11}$

\section{Плохие политические решения: де-баасификация и расформирова- ние иракской армии}

Вместо того, чтобы завоевывать сердца, умы и поддержку населения, некоторые решения Временной коалиционной администрации (ВКА) на начальном этапе интервенции были контрпродуктивными и привели к укреплению повстанческого движения. Двумя наиболее злополучными и проблематическими стратегическими решениями, которые влили жизнь и кровь в повстанческое движение и чьи последствия ощущаются до сих пор, были де-баасификация иракского общества и расформирование иракских сил безопасности.

Самым первым указом, изданным Полем Бремерем, главой ВКА, был указ о де-баасификации иракского общества. Согласно этому указу, члены партии БААС были уволены, и впредь им было запрещено занимать государственные должности. Кроме того, все лица, занимающие должности в министерствах или других государственных институциях, в том числе университеты и больницы, должны были пройти собеседование, и если устанавливалось, что они связаны с партией БААС, их освобождали от занимаемых должностей. ${ }^{12}$ Эта мера практически была направлена против ирак-

9 Anthony H. Cordesman, "Iraq: Too uncertain to call" (Centre for Strategic and International Studies, 2003), 2.

10 Sean Loughlin, "Rumsfeld on looting in Iraq: 'Stuff happens,'” CNN, April 12, 2003, по состоянию на 20 марта 2016, http://edition.cnn.com/2003/US/04/11/sprj.irq. pentagon.

11 Bruce Hoffman, "Insurgency and Counterinsurgency in Iraq," Studies in Conflict \& Terrorism 29, no. 2 (2006): 103-121, quote on pages 2-3.

12 Paul L. Bremer, "Coalition Provisional Authority Order Number 1: De-Ba'athification of Iraqi Society" (Coalition Provisional Authority, 2003), по состоянию на 1 марта 
ской суннитской общности, которая составляла большую часть членской массы партии БААС и высшего эшелона государственного управления, что не оставляло им никакой иной возможности, как ответить на удар.

Вторым указом ВКА, изданным 23 мая 2003 года, распускалась иракская армия и другие институции безопасности и отменялись «все военные или иные звания или статусы, данные бывшим режимом бывшим служащим или функционерам расформированных организаций». ${ }^{13}$ Это оставило около 230000 бывших иракских офицеров и сержантов вооруженных сил на улице, лишая их всякой надежды на будущую должность или карьеру. Хорошо подготовленные и вооруженные, многие из них присоединились к повстанческому движению под руководством аль-Заркави или к другим повстанческим группам. С того момента, баасисты и бывшие офицеры вооруженных сил формировали хребет повстанческого движения все эти годы. В 2006 году, 99 из 200 генералов старой иракской армии «вероятно, участвовали активно в повстанческом движении». ${ }^{14}$ Когда Абу Бакр альБагдади принял руководство группировкой, он начал в 2010 году агрессивную кампанию для вербовки баасистов и армейских офицеров с целью оживления ослабшего повстанческого движения. К примеру, 34 из 42 высших руководителей АКИ были убиты за очень короткий период времени, и аль-Багдади использовал эту возможность для заполнения этих вакансий бывшими баасистами и офицерами вооруженных сил, что рассматривалось как «иракизация» ИГ. ${ }^{15}$

По мнению бригадного генерала Хассана Дулайми, бывшего офицера разведки старой иракской армии, «люди, руководящие военными операциями в Исламском государстве, были лучшими офицерами в бывшей иракской армии, и поэтому Исламское государство побеждает нас в разведке и на поле боя». ${ }^{16}$ Согласно Саджаду Джияд, старшего аналитика и исследователя в Центре исследований и планирования аль-Баяна в Багдаде, более 25 из 40 наиболее выдающихся лидеров в 2014-2015 годах

2016, www.iraqcoalition.org/regulations/20030516_CPAORD_1_DeBa_athification_ of_Iraqi_Society_.pdf.

Paul L. Bremer, "Coalition Provisional Authority Order Number 2: Dissolution of Entities," Baghdad, May 23, 2003, по состоянию на 1 марта 2016, www.iraqcoalition.org/regulations/20030823_CPAORD_2_Dissolution_of_Entities_ with_Annex_A.pdf.

14 Bruce R. Pirnie and Edward O'Connell, Counterinsurgency in Iraq (2003-2006), Volume 2 (Santa Monica, CA: Rand Corporation, 2008), 26.

15 Michael Weiss and Hassan Hassan, ISIS: Inside the Army of Terror (New York: Simon \& Schuster, 2015), 120-21.

16 Liz Sly, "The hidden hand behind the Islamic State militants? Saddam Hussein's," Washington Post, April 4, 2015, по состоянию на 14 февраля 2016, https://www.washingtonpost.com/world/middle_east/the-hidden-hand-behind-theislamic-state-militants-saddam-husseins/2015/04/04/aa97676c-cc32-11e4-87304f473416e759_story.html. 
были бывшими членами партии БААС или офицерами вооруженных сил. Он считает, что «ИГИЛ, как организации, не существовало бы без бывших баасистов». 17

Многие из военных и гражданских лидеров США со временем осознали отрицательные последствия де-баасификации и распада иракских институций безопасности, но они не могут обратить или остановить этот процесс. Комиссия по де-баасификации продолжала действовать и имела свою роль в дисквалификации многих важных суннитских лидеров на парламентских выборах в 2010 году. Премьер-министр Малики арестовал большое число предполагаемых баасистов даже в 2011 году. ${ }^{18}$ Некоторые баасисты и бывшие офицеры армии присоединились к Движению пробуждения и воевали с Аль-Каидой во время «волны» военных действий в 2007 году. Однако, после ухода войск США, иракское правительство отказалось от Движения пробуждения и стало преследовать его лидеров, которым не оставалось ничего другого, кроме как присоединиться к ИГ. ${ }^{19}$

\section{Военная слабость: неспособность защитить население}

Интервенция США в Ираке страдала не только спорной юридической законностью и просчетами, но и недостаточными ресурсами и плохой контрповстанческой работой на ранних этапах. Хотя армию США считают лучшей военной силой, располагающей беспрецедентной передовой технологией и огневой мощью, она оказалась не готовой к борьбе с повстанцами. Она «вошла в Ирак в марте 2003 года без никакой доктрины, подготовки или иных приготовлений». ${ }^{20}$ Уроки практики войны во Вьетнаме не были интернализированы и были отброшены. И администрация Буша не была готова ввести требуемое количество войск для обеспечения безопасности и порядка в пост-саддамовском Ираке.

Полевой устав по борьбе с повстанцами Сухопутных войск и морской пехоты США предполагает, что для успешной контрповстанческой кампании нужны, как минимум, 20 военных на тысячу человек населения, что

17 Davide Mastracci, "How the catastrophic American decision to disband Saddam's military helped fuel the rise of ISIL," National Post, May 23, 2015, по состоянию на 14 февраля 2016, http://news.nationalpost.com/news/world/how-the-catastrophicamerican-decision-to-disband-saddams-military-helped-fuel-the-rise-of-isil.

18 W. Andrew Terrill, Lessons of the Iraqi De-Ba'athification Program for Iraq's Future and the Arab Revolutions (Carlisle, PA: U.S. Army War College, Strategic Studies Institute, May 2012), по состоянию на 12 апреля 2016, www.dtic.mil/dtic/tr/fulltext/ u2/a560673.pdf, p. $x$.

19 Sly, "The hidden hand behind the Islamic State militants?"

20 Brian Burton and John Nagl, "Learning as we go: the US army adapts to counterinsurgency in Iraq, July 2004-December 2006," Small Wars \& Insurgencies 19, no. 3 (September 2008): 303-27. 
предлагается и в другой контрповстанческой литературе. ${ }^{21} \mathrm{~K}$ примеру, в североирландской и малайской кампании британцы развернули количество войск из расчета 20 служащих в контрповстанческих силах на 1000 человек населения. Подобным образом, НАТО начало свою многонациональную операцию в Боснии с отношением более чем 20 солдат на 1000 человек населения. $^{22}$ При таком соотношении, в Ираке при населении в 30 миллионов для победы над повстанцами потребовались бы силы численностью в 600000 военнослужащих. Однако, в начале 2004 года в Ираке были развернуты войска численностью в 115000 солдат, и их численность не превышала 171000 (182 000 с британскими войсками) даже на пике «волны».

Недостаточные ресурсы означали, что силы США не могли защитить население и получить его поддержку, что является ключом к успеху согласно теориям борьбы с повстанцами. Это так же означало, что американские военные командиры не имели желания противостоять шиитским милициям и смутьянам, в частности, Муктаде ас-Садр и его «Армии Махди», что способствовало углублению сектантской проблемы и потере доверия к США и иракскому правительству. Кроме того, недостаточное количество солдат и ресурсов делали войска США и иракское государство неспособными обеспечить верховенство закона и предоставление основных услуг - средства, которые обеспечили бы им легитимность и поддержку народа.

Иначе говоря, слабость контрповстанческих сил, в данном случае войск США и иракского правительства, в том числе слабая легитимность, проблематические политические решения, отсутствие доктрины борьбы с повстанцами и недостаточные ресурсы и количество войск привели к ухудшению безопасности и к экспоненциальному нарастанию насилия в Ираке. Число нападений повстанцев увеличилось до 26496 в 2004 и до 34131 в 2005, число терактов с использованием импровизированных взрывных устройств (ИВУ) достигло до 1800 в месяц. Аль-Заркави совершал нападения против всех шиитов без разницы с целью спровоцировать сектантский конфликт, тогда как находящиеся под влиянием шиитов силы безопасности несли ответственность за случаи пыток и убийств без решения суда суннитов и подозреваемых в повстанческой деятельности. В результате взрыва гробницы в Самарре, которая является самой священной гробницей для шиитов, в феврале 2005 года повстанческое движение повернулось в сторону широкомасштабного сектантского насильственного конфликта. Шиитские эскадроны смерти вошли в суннитские области, начали без разбору убивать гражданских лиц, а суннитские экстремисты продол-

21 John A. Nagl, et al., The US Army/Marine Corps Counterinsurgency Field Manual (University of Chicago Press, 2008), 23.

22 James T. Quinlivan, "Burden of Victory: The Painful Arithmetic of Stability Operations," Rand Review 27, no. 2 (2003): 28-29. 
жили совершать самоубийственные теракты против шиитских гражданских лиц, жертвы среди гражданского населения увеличились до $34000 .^{23}$

\section{"Волна» и движение "Пробуждение»}

По мере продолжения повстанческого движения и насилия, вооруженные силы США продолжали учиться и адаптироваться. Когда высшим американским командующим в Ираке был назначен генерал Петреус, он содействовал опубликованию Полевого наставления Сухопутных войск и морской пехоты США по борьбе с повстанцами (FM 3-24). В январе 2007 года президент США Дж. У. Буш отдал приказ развернуть в Ираке еще дополнительные войска численностью в 20 000, что было названо «волной», а командиры на месте изменили свою стратегию борьбы с повстанцами.

По мнению австралийского эксперта по борьбе с повстанцами Дэвида Килкуллена, «волна - это не стратегия, тут имеет значение переключение на безопасность населения и резидентский, с высокой плотностью сил, долгосрочный подход». ${ }^{24}$ То же самое вытекает из Обращения о состоянии Союза президента Буша в январе 2007 года, в котором он описал цель «волны» следующим образом: «У наших войск есть четко определенная миссия: помочь иракцам зачистить и обезопасить район, помочь им защитить местное население и гарантировать, что иракские войска, которые останутся после нас, будут в состоянии обеспечить безопасность, в которой нуждается Багдад». ${ }^{25}$ Генерал-майор Иосиф Фил, командир многонациональной дивизии "Багдад», который отвечал за реализацию плана по безопасности Багдада, в феврале 2007 года описал цели плана следующим образом: «этой операцией правительство Ирака пытается показать иракскому народу и международному сообществу, что оно способно защитить всех своих граждан, вне зависимости от этнической принадлежности или принадлежности к определенной секте». ${ }^{26}$ В то же время американские командиры начали работу с суннитскими племенами и вообще с населением как часть Сахвы или движения «Пробуждение», которое смогло обратить их против АКИ, пока войска США не ушли из Ирака.

Можно утверждать, что смена стратегии, которая была направлена на защиту и получение поддержки населения, сработала. От наивысшей точки в конце 2006, к ноябрю 2007 насилие и нападения повстанцев упали до самого низкого уровня с 2004 года. Тогда как до «волны» в провинции

${ }^{23}$ Burton and Nagl, "Learning as we go: the US army adapts to counterinsurgency in Iraq."

24 David Kilcullen, "Don't Confuse the 'Surge' with the Strategy," Small Wars Journal (January 2007), по состоянию на 5 марта 2016, http://smallwarsjournal.com/blog/ dont-confuse-the-surge-with-the-strategy.

25 Там же.

${ }^{26}$ Kimberly Kagan, Iraq Report (Washington, D.C.: The Institute for the Study of War, 2007). 
аль-Анбар имели место до 300 нападений за неделю, в конце 2007 их число упало до 20. Также наблюдалось драматическое улучшение в состоянии безопасности в Багдаде. Потери гражданского населения, которые достигли 3000 в декабре 2006, к ноябрю 2007 были снижены на 70\%. Число нападений было уменьшено на $60 \%$, и сектантское насилие резко упало на $90 \% .{ }^{27}$

Значительную часть снижения уровня насилия можно отнести на счет усилий по разрешению политических проблем, в том числе за счет повышения инклюзивности и легитимности иракского правительства. Суннитское движение Сахва, или «Пробуждение», было очень эффективным для обращения суннитов против Аль-Каиды, и результатом этого стало существенное уменьшение насилия и ослабление повстанческого движения.

\section{Вывод войск США и возвращение повстанцев}

Хотя «волна» принесла значительные ресурсы, правильную, сфокусированную на населении стратегию борьбы с повстанцами, что привело к успеху в уменьшении насилия и ослаблению повстанческого движения, поддержка в США этой войны упала до самой низкой точки с начала интервенции. С политической точки зрения, демонстрировать готовность к долгосрочному присутствию войск США в стране было трудно. К тому же, иракское правительство тоже не было заинтересовано в продлении присутствия американских войск в Ираке. В 2008 году президент Буш и премьер-министр Ирака Малики подписали Соглашение о статусе сил, в соответствии с которым все войска США должны быть выведены из Ирака к концу декабря 2011 года.

Хотя есть разные мнения, можно утверждать, что имели место два основных фактора, способствующих улучшению состояния безопасности в Ираке в 2007 году. Во-первых, «волна» и применение сфокусированной на населении стратегии борьбы с повстанцами позволили американским и иракским войскам защитить население от повстанцев, которые больше не могли террором принуждать его к сотрудничеству. Рост насилия и числа потерь сил США и Ирака на начальных стадиях «волны» показывает, что повстанцы и шиитские милиции не решили просто перестать воевать скорее, новая стратегия жестко ограничила их способность продолжать воевать. Во-вторых, комбинированное влияние движения Сахва и защиты населения устранило сектантскую дилемму безопасности, с которой сталкивались сунниты. В результате этого, суннитские общины повернулись против АКИ и других экстремистов, что привело к существенному ослаблению повстанческого движения. Однако, с учетом того, что иракское правительство не могло обеспечить себе поддержку населения из-за своей сла-

27 Raymond T. Odierno, "The Surge in Iraq: One Year Later," Lecture \#1068 on National Security and Defense (Heritage Foundation, 13 March 2008), по состоянию на 12 марта 2016, www.heritage.org/research/lecture/the-surge-in-iraq-one-year-later. 
бости и политики в отношении мусульманских сект, преждевременный вывод войск США дал возможность повстанческому движению возродиться, и оно, в итоге, превратилось в ИГ.

\section{Административная слабость: неспособность обеспечить предо- ставление общественных услуг}

Согласно теориям борьбы с повстанческими движениями, население является центром тяжести, и его поддержка - это ключ к успеху той или другой стороны. В дополнение к политическим и военным мерам, силы для борьбы с повстанцами должны стремиться получить эту поддержку путем предоставления таких административных услуг, как образование, работа, здравоохранение и т.д. В Ираке после Саддама Хусейна, однако, иракское правительство не могло обеспечить должным образом предоставление населению основных услуг. Де-баасификация устранила многих квалифицированных и опытных сотрудников разных министерств, искалечив функционирование государственного управления. С другой стороны, де-баасификация и расформирование иракских институций безопасности оставило без работы сотни тысяч иракцев, в том числе десятки тысяч школьных учителей. ${ }^{28}$ Все это создало значительные административные проблемы для иракского правительства и урезало его способность обеспечить предоставление общественных услуг и обеспечить себе поддержку населения.

\section{Индоктринация и создание сетей в местах лишения свободы}

«Волна» и последующий сдвиг к сфокусированной на населении стратегии означал больше боевых и кинетических операций, что привело к задержанию тысяч повстанцев, которые содержались в местах лишения свободы под управлением США. Эти места лишения свободы использовались ИГИ, как “джихадистские университеты» для вербовки, индоктринирования, создания сетей и передаче умений между боевиками. Одним из главных центров содержания под стражей был лагерь Кэмп-Букка, в котором в 2007 году находились 26000 повстанцев и через который прошли более 100000 задержанных, в том числе и многие из лидеров Иг. ${ }^{29}$

Кроме Абу Бакр аль-Багдади, который провел в Кэмп Букка пять лет, девять других членов высшего руководства ИГ, в том числе заместитель аль-Багдади, Абу Муслим аль-Туркмани, высший военный лидер ИГ Хаджи Бакр (который был убит) и лидер иностранных боевиков Абу Касим отбывали сроки в этом месте. Имея в виду то, что повстанцы боятся собираться в одном месте, чтобы не стать мишенью для американских войск, Кэмп Букка был для них прекрасной возможностью быть вместе в течение месяцев и разрабатывать свои планы. Многие из людей, которые отбывали

28 Andrew Terrill, Lessons of the Iraqi De-Ba'athification Program for Iraq's Future and the Arab Revolutions, 24.

29 Weiss and Hassan, ISIS: Inside the Army of Terror, 83. 
срок в Кэмп Букка, имели связи с повстанцами, из-за чего, собственно, они там и находились. Однако, даже случайные партизаны или бывшие баасисты, у которых не было ничего общего с идеологией ИГ, превратились в хардлайнеров, пока отбывали срок в компании множества радикальных идеологов.

По мнению Ричарда Баррета, Кэмп Букка способствовал созданию и укреплению союза между членами АКИ и экс-баасистами. Многие баасисты, которые были в тюрьме одновременно с Абу Бакр аль-Багдади, стали высшими руководителями Иг. ${ }^{31}$ Через годы заключенные, которые освобождались, возвращались в повстанческое движение уже с усовершенствованными умениями и располагая более широкой сетью контактов. После того, как эта тюрьма была передана иракским властям в результате вывода американских войск, остававшиеся там заключенные были освобождены, что имело существенные отрицательные последствия в смысле повстанческого движения в Ираке и эволюции Иг. ${ }^{32}$

В двух словах, годы в Кэмп Букка были формирующими для ИГ. Радикальные исламисты, которые обеспечивали идеологию, перемешались и укрепили свой союз с баасистами, у которых были умения в сфере военного планирования, стратегии и управления. Это в конечном итоге превратило ИГ в могучую и смертоносную организацию, в псевдо-государство, которое имело лучшее управление, чем многие сирийские повстанческие группы, и, возможно, чем сирийское и иракское государства.

Подводя итоги, можно сказать, что интервенция США в Ирак в 2003 году способствовала восходу и консолидации ИГ, став стратегической причиной для повстанческого движения, а неэффективная стратегия США и иракского правительства борьбы с повстанцами позволили повстанческому движению набрать силу. Хотя «волна» развертывания войск США и изменение антиповстанческой стратегии успели ослабить повстанческое движение, отсутствие долгосрочного ангажемента и преждевременный вывод войск США привели к возобновлению действий повстанцев. И наконец, плохой менеджмент мест лишения свободы, находящихся под управлением США, сыграл важную роль в подъеме и консолидации Исламского государства, способствуя включению в сеть и индоктринации задержанных повстанцев.

30 Terrence McCoy, "Camp Bucca: The US prison that became the birthplace of Isis," Independent, November 4, 2014, по состоянию на 12 апреля 2016, www.independent.co.uk/news/world/middle-east/camp-bucca-the-us-prison-thatbecame-the-birthplace-of-isis-9838905.html.

31 Richard Barrett, The Islamic State, The Soufan Group Report, November 2014, по состоянию на 5 апреля 2016, http://soufangroup.com/wp-content/uploads/2014/ 10/TSG-The-Islamic-State-Nov14.pdf.

32 Cockburn, The Rise of Islamic State: ISIS and the New Sunni revolution, 88. 


\section{Конфликт между сектами и восход Исламского государства}

Конфликт между течениями ислама или этнический конфликт, как называют конфликт между шиитами и суннитами в Ираке и в регионе, является другим важным фактором, способствующим подъему и консолидации ИГ. Для анализа этой гипотезы в данной работе используются теории этнического конфликта. Хотя, строго говоря, этническая принадлежность и принадлежность к религиозным сектам - это не одно и то же, - в данной статье эти понятия будут использоваться, как синонимы, и шиизм и суннизм будут рассматриваться, как отдельные идентичности, подобные национальности.

\section{Исторические предпосылки конфликта между течениями ислама}

По традиции, политическая власть в исламском мире принадлежала суннитам. После исламской революции в Иране шииты начали увеличивать свою власть и влияние в разных странах, что стало причиной для беспокойства среди суннитских режимов на Ближнем Востоке. Союз Ирана и Сирии укрепил положение этих двух стран против находящихся под управлением суннитов их соседей. ${ }^{33}$ Создание Хезболла и ее проявление в качестве сильного игрока в Ливане и в сопротивлении против Израиля еще больше повысили самочувствие шиитов в этом регионе и за его пределами. И наконец, падение режима Саддама и приход на его место находящегося под влиянием шиитов правительства изменили баланс сил в этом традиционно суннитском регионе, усилив опасения и тревоги, выражаемые лидерами суннитов.

В 2004 году король Иордании Абдулла выразил озабоченность тем, что если в правительстве Ирака после интервенции будут доминировать шииты, «может появиться новая цепь шиитских движений или правительств, простирающаяся от Ирана, через Ирак и Сирию до Ливана ...». ${ }^{34}$ В сентябре 2005 года саудовский министр иностранных дел, Сауд бен Фейсал, раскритиковал войну в Ираке как «передачу Ирака Ирану», и выразил озабоченность иранским влиянием на иракских шиитов. В том же духе, в апреле 2006 года, Хосни Мубарак, являющийся тогда президентом Египта, раскритиковал иракских шиитов и шиитов других стран за то, что они более лояльны к Ирану, чем к своей собственной стране. ${ }^{35}$

Чтобы противодействовать иранскому влиянию, саудовцы начали пытаться распространять свою анти-шиитскую ваххабитскую идеологию путем финансирования мечетей, медресе и образовательных институций по

33 Vali Nasr, The Shia Revival: How Conflicts within Islam Will Shape the Future (New York: W.W. Norton \& Company, 2007).

34 Amir M. Haji-Yousefi, "Whose Agenda Is Served by the Idea of a Shia Crescent?" Alternatives: Turkish Journal of International Relations 8, no. 1 (Spring 2009): 11435.

35 Ibid. 
всему миру. $^{36}$ За период с 1982 по 2005 год Саудовская Аравия обеспечила финансирование 210 исламских центров, 1500 мечетей, 202 исламских факультета и 2000 школ по всему миру. В 2013 году страна предоставила 35 миллиардов долларов США школам в Южной Азии, в которой живет около одного миллиарда из 1.6 миллиардов мусульман в мире. ${ }^{37}$ Хотя в какой-то мере это имеет место из-за того, что саудовцы верят в ваххабизм и делают это в религиозных целях, нельзя пренебрегать фактом, что соображения, связанные с отношениями между шиитами и суннитами, также сыграли свою роль.

Благодаря щедрому финансированию, учение и влияние саудовского ваххабизма распространилось по всему миру. Это идеология, которая является интеллектуальной основой и вдохновителем большинства вооруженных экстремистских групп сегодня. По словам Сами Моубайед, без ваххабизма «сегодня не было бы никакой Саудовской Аравии, никакого Исламского государства в Ракке и никаких разговоров об Аль-Каиде или ИГИЛ». ${ }^{38}$

\section{Конфликт между течениями ислама в регионе и поддержка ИГ}

Конфликт между сектами ислама в регионе играет на руку ИГ двумя способами. Во-первых, он привел к щедрому финансированию повстанческих групп, что напрямую или косвенно идет на пользу ИГ. Во-вторых, религиозная поддержка суннитских племен ИГ усилила позиции группировки против иракского и сирийского государств. Кроме того, мотивированный сектантскими различиями конфликт в Сирии привел к ослаблению режима Асада, создав брешь, в которой ИГ может расширяться.

С конца 1970-х суннитские режимы в данном регионе опасались потенциальных волнений и появления повстанческих движений среди их шиитского населения. Можно утверждать, что одна из основных причин для войны Саддама против новоявленной Исламской Республики Иран был страх перед экспортом шиитской революции в Ирак. ${ }^{39}$ С учетом того, что большинство населения Ирака - это шииты, дилемма безопасности для Саддама состояла в выборе между нападением и уничтожением шиитского режима, пока он слаб, или иметь дело с шиитской революцией внутри страны, инспирированной или поддерживаемой Исламской Рес-

${ }^{36}$ Nasr, The Shia Revival: How Conflicts within Islam Will Shape the Future.

37 Bouthaina Shaaban, "The Rise of ISIS and Other Extremist Groups: the role of the West and Regional Powers" The Canadian Charger, February 19, 2016, по состоянию на 12 апреля 2016, www.thecanadiancharger.com/page.php?id= $5 \& a=1967$.

38 Sami Moubayed, Under the Black Flag: At the Frontier of the New Jihad (I.B. Tauris, November 2015), 11.

39 Thom Workman, "The Social Origins of the Iran-Iraq War," CISS Working Paper \#5 (Downsview, Ontario: York University, Centre for International and Strategic Studies, 1991). 
публикой Иран. Однако, хотя Саддаму не удалось свергнуть революционный шиитский режим, баланс сил был таким, что Иран не мог осуществить экспорт своей революции в Ирак или в другие большие суннитские страны. Несмотря на это, взаимные подозрения между Исламской Республикой Иран и суннитскими странами продолжали иметь место.

После свержения Саддама, которое нарушило баланс сил между исламскими сектами, противоречия между течениями ислама в регионе способствовали перекачиванию миллионов долларов из суннитских стран в регионе Персидского залива в Исламское государство. Страны Залива и Турция напрямую или косвенно поддерживали суннитские повстанческие группы в Сирии, надеясь скомпенсировать замену режима Саддама шиитским правительством путем замены режима Асада суннитской экстремисткой группировкой.

Саудовская Аравия продолжала оставаться главным источником финансирования для экстремистских группировок по всему свету. Согласно каблограмме, опубликованной Викиликс, государственный секретарь США, Хиллари Клинтон, писала в декабре 2009 года, что «Саудовская Аравия остается критически важным финансовым фундаментом поддержки для Аль-Каиды [...] и других террористических группировок». В 2007 году Стюарт Левей, заместитель министра финансов США по вопросам борьбы с терроризмом и контрабандой наркотиков, в одном интервью сказал: «если я мог бы как-то щелкнуть пальцами и пресечь финансирование из одной страны, это была бы Саудовская Аравия». ${ }^{40}$

В дополнение к прямому государственному финансированию, эти страны закрывают глаза на финансирование, текущее от богатых личностей, благотворительных организаций и других сетей к повстанческим группам. В 2012-2013 годах мешки с наличностью, наполненные миллионами долларов, текли по каналам через Турцию к повстанческим группам на регулярной основе. В 2013 и 2014 ИГ получило от стран Залива не менее 40 миллионов долларов США. ${ }^{41}$ Имея в виду ее проблемы с режимом Асада, Турция не заинтересована в пресечении потока денег, оружия и боевиков к повстанцам в Сирии.

\section{Конфликт между исламскими сектами в Ираке и восход Исламского государства}

Интервенция США в Ираке и свержение Саддама изменили политическое уравнение страны. После долгих лет дискриминации и преследований, шииты стали управляющей прослойкой в новом демократическом Ираке. Они

40 Moubayed, Under the Black Flag: At the Frontier of the New Jihad, 11-12.

41 Matthew Levitt, "Terrorist Financing and the Islamic State," Testimony submitted to the House Committee on Financial Services, November 13, 2014, Washington Institute, по состоянию на 29 марта 2016, www.washingtoninstitute.org/uploads/ Documents/testimony/LevittTestimony20141113.pdf. 
считали, что это их право в соответствии с принципом власти большинства, и готовы были защищать это право любой ценой. В то же время де-баасификация и расформирование иракской армии на практике означали лишение суннитов политической власти, что было неприемлемо для суннитской общины. А как предполагали Ларс-Эрик Седерман, Андреас Уиммер и Брайан Мин, этнические группы готовы воевать, если они потеряли власть недавно. 42 Таким образом, это стало мотивирующим фактором для суннитов, чтобы они присоединились к повстанцам и начали воевать с находящимся под управлением шиитов государством и их сторонниками из-за рубежа.

Другим, возможно более важным фактором для сектантского насилия является связанная с сектами ислама проблема безопасности, которая возникла после падения Саддама. Когда империя, государство или центральная власть распадается или становится настолько слабой, что не может обеспечивать порядок и безопасность своих граждан, возникает проблема безопасности, связанная с этническими или объединенными по другому признаку идентичности группами. В такой ситуации, каждая группа берет на себя ответственность за свою собственную безопасность и пытается обеспечить ее путем приобретения вооружений или созданием своей собственной этнической армии для своей защиты. ${ }^{43}$ В Ираке не только возникла такая связанная с сектами ислама дилемма, порожденная падением Саддама и последующим распадом институций безопасности, но она была кроме того спровоцирована и усилена АКИ.

Заркави, как многие другие такфиристы, остро презирал шиитов, но так же «использовал то, что было новой, но реальной проблемой в политической эволюции Ирака: ползучий захват государственных институций шовинистическими шиитскими политиками». ${ }^{44}$ После падения режима Саддама, расформирования старой иракской армии и программы де-баасификации, суннитские общины думали, что они брошены на милость своих шиитских противников, поддерживаемых Ираном. Заркави стремился к обострению этой связанной с сектами проблемы безопасности и к привлечению суннитов к повстанческому движению. Как показывает его письмо Бен Ладену от 2004 года, он вознамеривался разжечь массовое сектантское насилие в Ираке, чтобы у суннитов не осталось иного выбора, кроме как обратиться к АКИ для защиты:

преследуя и нанося шиитам удары в [их] религиозную, политическую и военную глубину, спровоцировать их на то, чтобы они показали суннитам свое бешенство и оскал скрытой злобы, клокочущей в их груди.

42 Lars-Erik Cederman, Andreas Wimmer, and Brian Min, "Why Do Ethnic Groups Rebel? New Data and Analysis," World Politics 62, no. 1 (January 2010): 87-119.

43 Michael E. Brown, ed., Ethnic Conflict and International Security (Princeton University Press, 1993), 103-10.

${ }^{44}$ Cockburn, The Rise of Islamic State: ISIS and the New Sunni Revolution, 29. 
Если мы сможем втянуть их на арену сектантской войны, станет возможно разбудить безразличных суннитов, которые почувствуют надвигающуюся опасность и угрожающую уничтожением смерть от рук этих звездопоклонников. ${ }^{45}$

К 2006 году Ирак оказался в разгаре жестокого и насильственного сектантского конфликта. Взрыв в священной для шиитов гробнице в Самарре привел к беспрецедентному пику сектантского насилия, при котором гражданское население как из шиитских, так и из суннитских общин стало объектом нападений эскадронов смерти другой стороны. Шиитские милиции входили в районы, населенные суннитами, и убивали сотни людей в отместку за взрыв усыпальницы, тогда как суннитские экстремисты совершали самоубийственные нападения на шиитов. Массовые убийства и похищения стали обычным явлением, а трупы выбрасывали прямо на улицы.

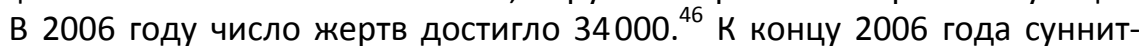
ское сообщество было загнано в угол и верило, что единственным защитником и спасителем от жестокой смерти от рук шиитских милиций были АКИ и другие суннитские экстремистские группы. ${ }^{47}$ Как показано на фигуре ниже, общее число террористических нападений в ноябре 2006 года превысило 5000. ${ }^{48}$

Как раз на пике сектантского насилия были осуществлены «волна» и Сахва (движение «Пробуждение» суннитов). Стратегической целью обеих мероприятий была защита населения и разрешение дилеммы безопасности, связанной с борьбой сект. Безопасность суннитских общин начали обеспечивать Сыны Ирака, коалиция иракских племен, вооружаемые и финансируемые вооруженными силами США. Суннитские племена, которым уже не было необходимо обращаться для защиты к Аль-Каиде, обратились против нее, что привело к существенному снижению уровня насилия и ослаблению повстанческого движения.

Однако, после того, как войска США были выведены, а иракское государство отказалось от движения «Пробуждение», дилемма безопасности, связанная с борьбой сект, снова интенсифицировалась, что толкнуло суннитов в сторону ИГ. Абу Бакр аль-Багдади использовал ту же стратегию провоцирования дилеммы безопасности, связанной с сектантским насилием, используя «сектантскую экзистенциальную грамматику» Заркави, в

45 Там же.

46 Burton and Nagl, "Learning as we go: the US army adapts to counterinsurgency in Iraq."

47 David Kilcullen, The Accidental Guerrilla: Fighting Small Wars in the Midst of a Big One (New York: Oxford University Press, 2009), 127.

48 Michael E. O'Hanlon and Jason H. Campbell, Iraq Index - Tracking Variables of Reconstruction \& Security in Post-Saddam Iraq, Brookings Institution Report (December 2008), по состоянию на 29 марта, 2016, https://www.brookings.edu/wpcontent/uploads/2016/07/index20081218.pdf. 


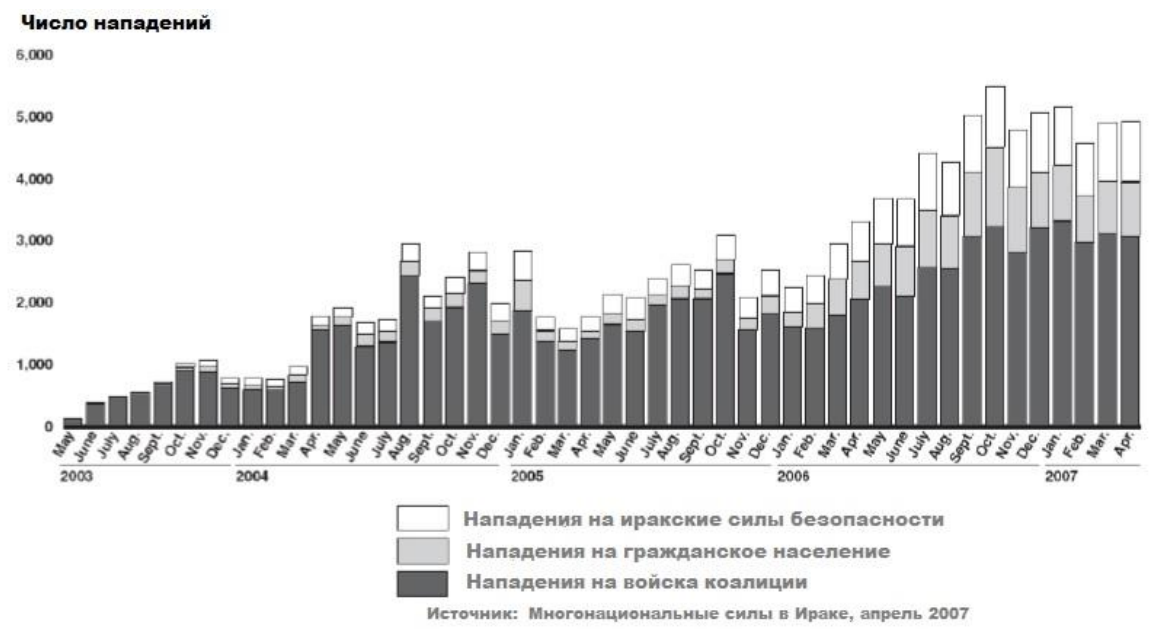

Фигура 1: Enemy-initiated attacks against the coalition and its partners.

то же время выставляя себя защитником суннитов в Ираке и Сирии. ${ }^{49}$ Террористические группировки продолжили убивать иракское гражданское население и членов иракских сил безопасности на сектантской основе. В июне 2014, после оккупации Мосула, ИГ казнило 1700 иракских солдат. ${ }^{50}$ Таким же образом, после захвата Тикрита, боевики ИГ разделили сдавшихся солдат на две группы - шиитов и суннитов, и все шииты были убиты. Эти факторы, конечно, интенсифицировали сектантские конфликты с серьезными последствиями для региона и всего мира.

\section{Политика премьер-министра Малики по вопросу борьбы между сектами и возвращение повстанцев}

С уменьшением присутствия и влияния США в Ираке правительство Малики становилось все более сектантским. Движению «Пробуждение» постепенно был положен конец и его лидеры начали подвергаться преследованию со стороны шиитов, доминирующих в силах безопасности. Наиболее проблематической была ситуация в провинции Дияла. После того, как премьер послал силы для специальных операций, чтобы арестовать президента университета Диялы и члена местного совета, что привело

49 Weiss and Hassan, ISIS: Inside the Army of Terror, 29.

50 Simon Tomlinson and Amy White, Mail Online, 13 June 2014, по состоянию на 4 августа 2016, www.dailymail.co.uk/news/article-2656905/ISIS-jihadists-seize-twotowns-bear-Baghdad-U-S-tanks-helicopters-stolen-fleeing-western-trained-Iraqiforces.html. 
к смерти пресс-секретаря губернатора, ситуация в провинции вышла изпод контроля. ${ }^{51}$

В провинции Анбар полковник Саад Аббас Мохамед, командир 3000 сынов Ирака, по его собственным словам, был объектом 25 покушений на убийство. Программа, разработанная США для переведения 30000 добровольцев движения «Пробуждение» на государственную службу, не была реализована. Члены движения «Пробуждение» начали возвращаться в повстанческое движение, находившееся уже под руководством более амбициозного лидера, Абу Бакр аль-Багдади. Согласно мулле Надиму Джибури, в 2010 году АКИ на 40 процентов состояла из бывших Сыновей Ирака, которые переметнулись из-за разногласий, снова появившихся между правительством и суннитскими племенами. ${ }^{52}$

Можно утверждать, что Малики разыгрывал сектантскую карту с целью укрепить свою базу поддержки в шиитском сообществе с прицелом на выборы, но последствия этого для страны были разрушительными. На выборах в 2010 году господин Малики получил на два места меньше, чем блок его соперника Айада Алави. Тем не менее, он успел сформировать правительство с помощью вмешательства Ирана. С тех пор он стал еще более сектантски настроен. В декабре 2011 года он приказал арестовать двоих из высших лидеров суннитов, Рафи аль-Иссами, министра финансов, и Тарика аль-Хашими, вицепрезидента Ирака, по обвинению в терроризме. Господин Хашими бежал в Курдистан и заочно был приговорен к смерти. Эти и другие сектантские действия Малики привели к массовым демонстрациям в преобладающе суннитских районах Ирака. В апреле 2013 года иракская армия взяла штурмом мирный лагерь в Хавидже, западнее Киркука, убив более пятидесяти мирных суннитов. Этот инцидент и другие имевшие основание обиды превратили протесты в повстанческое движение и привели к всплеску насилия во всем Ираке с нападениями в духе Аль-Каиды на поселения шиитов и нападениями на суннитские мечети. ${ }^{5}$

Хотя сектантская политическая кампания господина Малики, основанная на спекуляции страхами людей, которая была построена вокруг суннитской контрреволюции, помогла ему победить на выборах в 2014 году, она сработала и на пользу Багдади. Чуть больше года после начала массовых протестов суннитов, во время которых Малики не сделал никаких уступок, ИГ дошло до окрестностей Багдада. К июню 2014 года, с помощью местных суннитов, ИГ захватило суннитские провинции Ниневия, Салахуддин и части Даялы и объявило о создании халифата. ${ }^{54}$

\footnotetext{
51 Weiss and Hassan, ISIS: Inside the Army of Terror, 90.

52 Там же, 91.

53 Там же, 96-97.

54 Cockburn, The Rise of Islamic State: ISIS and the New Sunni Revolution, 48.
} 


\section{Заключение}

В этой исследовательской работе рассматривается вопрос о степени, в которой интервенция США в Ирак в 2003 году и сектантский конфликт в стране и в регионе способствовали восходу и консолидации ИГ. Основываясь на вышеприведенном анализе, можно утверждать, что интервенция США в 2003 и этнический конфликт в Ираке действительно способствовали подъему и консолидации ИГ. Тогда как интервенция США способствовала подъему, популярности и расширению повстанческого движения, сектантский конфликт способствовал консолидации и укреплению группировки.

Показано, что интервенция США в Ирак и ее последствия способствовали восходу и консолидации ИГ следующим способом: во-первых, она дала стратегическое основание для мобилизации и расширения популярности повстанческого движения, которое в итоге превратилось в ИГ. Вовторых, слабость структур, борющихся с повстанцами, рассматриваемая как предварительное условие для успешного повстанческого движения, позволила восстанию разрастись. Политическая слабость структур для борьбы с повстанцами проистекала из их недостаточной легитимности, отсутствия плана действий на период после интервенции и таких ошибочных политических решениях, как де-баасификация и расформирование иракской армии. Военная слабость проистекала из недостаточного количества войск и отсутствия доктрины борьбы с повстанцами на начальном этапе интервенции.

Хотя вооруженные силы США адаптировали свою стратегию и развернули дополнительные войска, что привело к снижению уровня насилия и ослаблению повстанческого движения, отсутствие долгосрочного ангажемента со стороны США, недоброжелательное отношение иракского правительства и преждевременный вывод войск США привели к возобновлению повстанческого движения. И последнее, административная слабость выражалась в неспособности обеспечить предоставление общественных услуг и в ограниченной способности завоевать умы и души населения. Далее, было показано, что находившиеся под руководством США места лишения свободы стали джихадистскими университетами для индоктринации боевиков и создания сети высших лидеров АКИ, которые затем приняли на себя ответственность за руководство Исламского государства.

Было показано, что сектантский конфликт в Ираке и в регионе способствовал восходу и консолидации ИГ следующим способом. Во-первых, дилемма безопасности, связанная с сектантским конфликтом, после исламской революции в Иране подвигнула Саудовскую Аравию на принятие решения начать финансировать распространение салафизма/ваххабизма идеологии, которая вдохновляет экстремистские группировки и обеспечивает интеллектуальные основы ИГ. Во-вторых, свержение Саддама еще больше усилило дилемму безопасности, связанную с сектантством, и финансирование Саудовской Аравией и ее союзниками повстанческих групп, с целью уравновесить сдвиг центра тяжести власти в регионе в сторону 
шиитов. Продолжение конфликта в Сирии позволило ИГ захватить большие участки территории и объявить Ракку своей столицей. И последнее, сектантская политика премьер-министра Малики и исключение иракских суннитских общин из власти привело к тому, что они начали поддерживать ИГ, усиливая его способность захватывать суннитские провинции в Ираке, и, в конечном итоге, объявить о создание халифата.

Из этого анализа можно сделать несколько выводов и рекомендаций в отношении политики по данному вопросу. Исламское государство является очень совершенной политической, военной и идеологической террористической группировкой, которая использует конфликт между сектами ислама и внешнюю интервенцию, чтобы мобилизовать боевиков и оправдать их зверства. Чтобы победить эту группировку, нужны правильное политическое решение, сильная воля и готовность принимать на себя обязательства в долгосрочном плане. Во-первых, политическое решение, которое разрешит дилемму безопасности, а также обеспечит политические, экономические и религиозные права суннитских сообществ в Ираке и в Сирии, является обязательной предпосылкой для победы над этой террористической группировкой. Во-вторых, нужна рассчитанная на долгосрочный период, сфокусированная на населении, стратегия борьбы с повстанцами, которая очистит территорию от ИГ и будет держать террористов в стороне, защищая население и обеспечивая его безопасность. В-третьих, для обеспечения долгосрочной безопасности и стабильности в регионе необходимо региональное соглашение, которое будет учитывать опасения в сфере безопасности основных региональных игроков - Ирана, Саудовской Аравии и Турции.

Еще одним уроком является вывод, что внешняя интервенция создает стратегическое основание для мобилизации и может усилить повстанческое движение. Кампании борьбы с повстанцами требуют долгосрочной ангажированности и значительных ресурсов, что часто трудно обеспечить или перевести на место. Поэтому, на первом месте лучше не вмешиваться, если это возможно. Однако, когда интервенция неизбежна, она должна быть хорошо спланированной, обеспеченной ресурсами, легитимностью и долгосрочной готовностью убеждать население и повстанцев, что государство в конечном итоге победит. Как «волна» и некоторые другие случаи интервенции, например в Северной Ирландии, Малайе и интервенция НАТО в Боснии показали, хорошо спланированная и обеспеченная ресурсами кампания борьбы с повстанцами с долгосрочными обязательствами может действительно стабилизировать ситуацию и победить повстанческие силы. 


\section{6 авторе}

Абдул Басир Йосуфи является генеральным директором по международному сотрудничеству в Министерстве внутренних дел Афганистана, где раньше, с 2010 года, он работал старшим политическим советником и аналитиком по политике министерства. До того как поступил на государственную службу, он работал в частных и неправительственных организациях. Он получил степень магистра по передовым исследованиям европейской и международной безопасности в ЖЦПБ и Университете Женевы в 2016 году, а также степень магистра наук дипломатической службы в Школе дипломатической службы Джорджтаунского университета в 2010 году. Он закончил бакалаврскую программу по политическим наукам в Университете Дели в 2006 году. Также получил несколько стипендий и наград, в том числе Фулбрайтовскую стипендию, награду за академические достижения декана ШДС Джорджтаунского университета и магистерскую награду ЖЦПБ/Университета Женевы за наиболее выдающуюся исследовательскую работу. Он говорит на персидском, пуштунском и английском языках, на языках урду, хинди и немного на арабском. В круг его исследовательских интересов входят безопасность в Южной Азии, контр-терроризм, контр-повстанческие действия и реформа сектора безопасности. 